\title{
Predictors of Early-Career Self-Employment among Millennials in the Digital Economy: The Role of The Great Recession
}

\author{
Maria Figueroa-Armijos \\ American University \\ maria.figueroa@american.edu
}

\author{
Serge P. da Motta Veiga \\ American University \\ serge@american.edu
}

\begin{abstract}
In today's digital economy, millennials seek flexibility and task significance, making selfemployment an attractive career option. Although millennials are growing to become the largest generation in the United States workforce, evidence is scant regarding what drives their self-employment decisions. This study explores predictors of selfemployment among early millennials (i.e. those born between 1980 and 1984) in the years before, during, and after The Great Recession. Using a national U.S. database (NLSY97), we find that millennials who were satisfied with their early-career jobs were more likely to become self-employed before the recession, and also after the recession. During the recession, however, our indicator of job satisfaction is nonsignificant, although the coefficient indicates an inverse relationship. Our results also suggest that higher autonomy (less parental monitoring) during adolescence is positively related to millennials' selfemployment decision in their early-career stage, especially among women and those who grew up in an urban area.
\end{abstract}

\section{Introduction}

Millennials (those born between 1980 and 1995; [83]), who have been labeled "digital natives" [37], seek work-life balance, flexibility, and making a difference in their organization above higher pay or other extrinsic work values (e.g. [17]; [63]; [79]). They have distinctive career goals and expectations than previous generations (i.e., Generation X, Baby Boomers). It is more difficult for them to find the right job and they end up changing jobs more often (i.e. job hopping; [63]). Since not all jobs are likely to satisfy millennials' need for work-life balance, flexibility, and task significance, they are likely to look into alternative career options.

In today's digital economy, self-employment provides an alternative career option that is not driven by wealth, but instead by lifestyle and contribution [1]. Amit et al. [1] define the lifestyle motivator as 'accommodating dual career situations, spending time with family, in recreational opportunities, living where you want, having fun, and being healthy', and the contribution motivator as 'helping others, making a difference to your organization, community, industry and creating opportunities' (p. 143). Furthermore, selfemployment is likely to provide greater employment stability, especially for individuals who tend to hop from one job to another [32], such as millennials.

Thus, self-employment seems to present a good fit for millennials' career goals and expectations. Indeed, people are attracted to work settings that align with their values and interests ([14]; [51]; [57]). Prior research has examined various determinants for the decision to pursue self-employment over paid employment, such as autonomy, flexible work hours, increased job satisfaction, or getting away from bureaucracy ([33]; [49]). But what factors drive millennials to pursue self-employment over other career options, including paid employment? Since millennials have different career goals and expectations, the factors driving their decision to pursue self-employment might differ from previous generations.

In this study, we align research on millennials and self-employment in the digital economy [39] with research on sustainable careers [22] to investigate the dynamics driving millennials' self-employment decisions, ranging from job satisfaction and personality traits to the influence of parental monitoring. Using a comprehensive national database (National Longitudinal Survey of the Youth 1997, NLSY97), we further analyze these predictors by gender and location (urban-rural) to examine differing characteristics between millennials in each group.

This study contributes to the entrepreneurship and careers literatures in the following ways. First, this study answers calls for self-employment research to take on a careers perspective, and to consider the context which shapes an individual's career path [13]. As such, we examine the role of individual, family, and contextual predictors in influencing millennials' self-employment career decisions. Second, this paper addresses the need for more research on millennials and the digital workforce ([39]; [52]), as most of the empirical studies to date focus on millennials as students [21]. We focus on a sample of early 
millennials (i.e. born between 1980 and 1984) as they enter the workforce and make important career decisions. Finally, this study addresses recent calls to examine 'sustainable' careers over time [22], by examining predictors that influence millennials' decisions to pursue self-employment as an alternative career option in the digital economy. This is also consistent with the idea that self-employment can provide a more stable career option than paid employment, especially to prevent job hopping [32].

\section{Background and Hypotheses}

\subsection{Millennials and the digital economy}

Millennials, those born between 1980 and 1995 [83], also known as "digital natives" [37], "Generation Y" [44], "the next great generation" [38], and the "Gen Me" [80], have different work values [55] and work preferences ([64]; [79]) than the generations before them (i.e. Generation X, Baby Boomers). Not surprisingly, as they grow to become "the largest generation in the current United States workforce," evidence suggests they are more likely to lead in innovative roles at work which differ from previous generations (p. 82) [3].

More importantly, despite their high educational achievement and digital skills, evidence suggests that this generation is experiencing persistent high unemployment rates and underemployment [34] which risks the rise of a trend of confidence loss among early-career workers [40]. Given longitudinal constraints, most research to date on millennials and their aspirational work values corresponds to surveys conducted when respondents had not yet fully achieved full-time employment, when were in their teens and early 20's (e.g. [12]; [55]; [64]; [79]). Researchers attribute age and developmental experiences as indicators of generational differences [58], therefore the practical implications of research conducted during millennials' late teens and early 20's may differ in accuracy from research conducted later in their careers, when they join the workforce [53].

Empirical evidence to inform this phenomenon is emerging. For instance, new evidence suggests that despite other previously stated values, millennials are still driven by income factors when choosing among career choices [29]. A recent study on millennials in the nonprofit sector [60] found that despite millennials' attraction to the mission of NGOs, those with positions of management or with advanced education are more likely to leave due to low pay.

Work values are the most stable (i.e. least likely to change) when an individual achieves young adulthood, which typically corresponds to the time when they enter the workforce ([42]; [50]). Recent evidence suggests that millennials' most desired work attributes include meaningful job content ([21]; [29]), opportunity for career advancement [21], work-life balance [17], and flexibility at work ([5]; [12]), all in a nurturing and constructive work environment [59].

\subsection{Millennials and The Great Recession}

The Great Recession, also known as the global economic recession, occurred between 2008 and 2010, and affect all generations, not just millennials [23]. Nevertheless, there is evidence suggesting that the 1829 age group (i.e. millennials) are those who suffer the most during a major recession ([23]; [68]). More specifically, individuals early in their careers are seeking opportunities for promotion and training, which are less likely to come across during a recession [68]. In these circumstances, self-employment provides an alternative career path, which offers higher autonomy, flexibility, and learning [1] for millennials seeking to jumpstart their career.

Furthermore, despite both experiencing similar macro-economic conditions, research suggests that women and men are affected differently by economic and political conditions during recessionary times [85], with varying effects observed by age group [86]. These differences are further exacerbated by location (urban-rural) of millennials. Current studies suggest that millennials prefer dense urban areas which offer walkability and transit options, offering greater accessibility to business and career opportunities [88].

\subsection{Self-employment as an alternative career option for millennials}

Job stability is an important determinant of individuals' career choices, with implications on both the supply and demand side [41]. Although, selfemployment "is often portrayed as a risky, unstable career path," (p. 163) [32] recent advances at the intersection of entrepreneurship and careers research are finding that self-employment offers greater job stability when the individual is willing to move [32]. In fact, self-employment is increasingly identified as a "bridge" [31] or "stop-gap measure" [13] that leads individuals to identify the best career option at a point in time. Indeed, periods of self-employment may be short ([46]; [77]) or meant to provide a transition to better-fitting wage employment [32] later on. Thus, self-employment may serve as a transitory career path in the individual's agency continuum that further enhances their employability chances, therefore leading to a more sustainable career [82]. As Burton et al. (p. 241) [13] explain, self-employment "should be 
viewed more like marriage than like death; exit is possible and indeed common."

Furthermore, the drastic changes observed in the contemporary workforce has led the scientific community to revisit the concept of self-employment beyond an attractive albeit risky occupation, to be considered as a "life-course related" choice for individuals [20]. Indeed, scholars have become more interested in the "why" of self-employment, rather than the "when", focusing on internal motivations that lead individuals to experiment [56] and choose selfemployment [27] over other career paths.

To address this important research question, a careers perspective on self-employment is suitable and timely. A careers lens to the study of self-employment shifts our focus towards the changing temporal [13] conditions of the context (i.e. family, organization), while also focusing on a comparative examination of career paths [28]. This long-term approach facilitates greater identification of human capital which occurs prior, during, or after self-employment [13].

A significant advance in careers research is the emergence of frameworks on sustainable careers ([22]; [71]). These novel inclusive frameworks allow us to revisit self-employment in the context of personal and contextual shifts, such as family influencers and restrictive path dependencies in the individual's career choices [30]. Prior research suggests that individuals seeking self-employment are driven by monetary (i.e. income; [36]; [71]) and nonmonetary rewards ([2]; [4]; [71]; [81]). Regarding the former, research finds that the self-employed make about three times the earnings of wage employees [74]. Among non-monetary rewards, individuals seeking self-employment are characterized by a higher tolerance for risk ([28]; [48]), a personal desire for higher independence ([9]; [47]), and a stronger preference for decision-making autonomy [28].

Millennials' expectations of achieving meaningful jobs ([21]; [29]), which offer flexibility ([5]; [12]), work-life balance [17], opportunities to grow [21], and high pay [60] align synchronously with the characteristics of sustainable career frameworks arising in the careers and HRM fields. The current lifestage of the first millennials in the workforce (i.e. those born between 1980 and 1984) positions them at the early-career stage in the United States digital workforce, during young adulthood, where work values are the most stable (i.e. least likely to change) ([42]; [50]). This timely prospect offers researchers the opportunity to delve into the practical underpinnings of millennial's work expectations and current realities in the workplace, without delay. The present study seeks to unveil key individual, parental, and contextual characteristics of millennials that influence their decisions to pursue self-employment as a sustainable career option in today's digital economy.

\subsection{Predictors of self-employment for millennials in the digital economy}

Millennials are unlike previous generations in that they have different career expectations, such as worklife balance, flexibility, and making a difference in their organization ([63]; [79]). In this study, we focus on three types of predictors that are likely to influence millennials' choice to pursue self-employment as a sustainable career in the digital economy: individual (job satisfaction, personality, gender), family (parental monitoring), and contextual (location while growing up, urban-rural).

2.4.1. Job satisfaction. Job satisfaction is a salient indicator [69] of predictors of self-employment [61], and a comprehensive marker of an individual's utility from a job [19]. Nonetheless, evidence regarding the effect of job satisfaction on self-employment decisions remains mixed ([45]). Notably, evidence indicates that self-employment leads to higher job and life satisfaction than for paid employees (e.g. [6]; [8]; [10]; [26]; [61]). For example, Benz and Frey [6] found that self-employed individuals in 23 different countries tend to have higher job satisfaction, which is for the most part due to more interesting jobs and greater autonomy.

Although prior research shows significant differences in job satisfaction between self-employed and paid employees, little research has examined whether and how the level of job satisfaction individuals have in their paid job is likely to influence their decision to pursue self-employment ([35]; [66]). Specifically, Noorderhaven et al. [66] found that lower levels of job satisfaction were positively related to self-employment levels. In this study, we are interested in examining whether and to what extent job satisfaction will influence a millennial's decision to become self-employed, as an alternative career option in the digital economy.

Consistent with prior research ([35]; [49]; [66]), paid employees are most likely to switch to selfemployment to increase their autonomy and independence and/or to increase their job satisfaction. As such, we expect that those with lower levels of job satisfaction will not only switch to self-employment but remain self-employed as a way to increase their job satisfaction. We thus hypothesize the following:

Hypothesis 1: Job satisfaction will be negatively related to self-employment decisions.

2.4.2. Personality facets. Although the role of 
personality in self-employment and entrepreneurship has been debated (for a recent review, [73]), we follow recent calls to further examine whether and how personality might influence the decision to pursue selfemployment or entrepreneurial ventures ([73]; [84]). More specifically, we are interested in further understanding whether some personality facets tend to facilitate a millennial's decision to become selfemployed, while also extending prior research (e.g. [15]; [54]) by studying whether and how personality influences the sustainability of the self-employment decision in the digital economy. As such, we are interested in the role of these personality facets for millennials (i.e. digital natives), who tend to have different personalities than their predecessors (e.g. [23]; [78]). Specifically, Twenge and Campbell [78] reviewed whether and how millennials differed from previous generations in extraversion, openness to new experiences, or locus of control.

Evidence indicates that personality facets, such as the Big Five personality traits (i.e. openness to experience, conscientiousness, extraversion, emotional stability, and agreeableness), influence whether and to what extent individuals are successful in entrepreneurial ventures. For example, in their meta-analyses, Zhao et al. [84] found that four of the Big Five personality traits were related to entrepreneurial intentions. Specifically, they found that conscientiousness, openness to new experiences, emotional stability, extraversion, and risk propensity were positively related to an individual's entrepreneurial intentions [84]. Interestingly, though, the only facet they found that was not related to such intentions was agreeableness. In another study, Caliendo et al. [15] found that openness to experience, extraversion, and risk tolerance were positively related to the decision to become self-employed.

In this study, we extend prior research (e.g. [15]; [54]; [84]) to examine whether and how various personality facets that have been shown to relate (or not) to entrepreneurial intentions and success influence millennials' decision to become selfemployed in the digital economy. Specifically, millennials tend to vary in their personality compared to previous generations [78], and we are thus interested in examining which personality facet(s) influence self-employment decisions over time.

2.4.3. Parental monitoring. Parental monitoring refers to parental awareness, watchfulness and supervision of adolescent activities in multiple domains (i.e. friends, school and behavior at home) [25]. It has received little attention in the selfemployment, the digital economy, or the careers literatures (for exceptions see [24]; [75]). Interestingly, Schmitt-Rodermund [75] examined and found that authoritative parenting, the most strict-type parental style, was positively related to entrepreneurial competence, although her sample did not include millennials. Overall, though, prior research has failed to examine the longitudinal influence of parental monitoring on millennials' career outcomes.

While prior research shows that parental role models can influence one's decision to become selfemployed, especially when parents are entrepreneurs themselves (e.g. [18]; [62]), little to no research has examined the role that parents have on their children's career aspirations and accomplishments. Although parental monitoring is important in terms of adolescent behavioral development and academic achievement [25], it has also been shown to be related to career aspirations [43]. As such, parental monitoring is likely to influence millennials' decision to pursue selfemployment as a career path in the digital economy. Specifically, millennials, who tend to suffer from helicopter parenting (i.e. very high levels of parental monitoring), also tend to be more dependent on others, possess less effective coping skills ([67]), and also possess lower student self-efficacy and maladaptive responses to workplace scenarios [11].

Since self-employment involves dealing with risk, stress, as well as responding to unexpected situations, we expect that more autonomy (i.e. lower parental monitoring) for millennials will be positively related to the decision to become self-employed, which is consistent with research by Lange [54]. We thus hypothesize the following:

Hypothesis 2: Parental monitoring will be negatively related to self-employment decisions

\section{Method}

\subsection{Sample}

This study uses data from the U. S. National Longitudinal Survey of Youth (NLSY97), a nationally representative sample of 9,022 millennials who were born between 1980 and 1984, and were thus between 13 and 17 years old when they were first interviewed in 1997. The NLSY97 was started and is managed by the U. S. Bureau of Labor Statistics. Participants in the NLSY97 were first interviewed in 1997. For this study, we use logit regression analysis to examine predictors of self-employment engagement between 2005 and 2011, when millennials are in age range 2131. The final sample for our study is 1,633 due to missing responses on certain variables. Our final sample consisted of $49 \%$ women, with $51 \%$ being nonBlack and non-Hispanic, and $76 \%$ of the respondents living in an urban area. 


\subsection{Dependent variable}

Our dependent variable of interest if selfemployment decision, a binary variable which equals 1 if the millennial was self-employed at each survey time period (2005 through 2011), and 0 if the millennial was not self-employed.

\subsection{Independent variables}

At the person-level, our predictors of selfemployment include millennials' early-career job satisfaction, measured in 2004 (for before the recession), 2006 (for during the recession), and 2009 (for after the recession). Job satisfaction is a continuous variable, which ranges from one to five, with five indicating the highest job satisfaction with current employer $(5=$ like it very much) and one indicating the lowest job satisfaction $(1=$ dislike it very much) with current employer. We also examined gender as a person-level predictor of self-employment. Gender is a binary variable coded as 1 if the millennial is male and 0 if the millennial is female.

The person-level predictors also include various personality facets, measured in 2002, including whether the millennial is agreeable, conscientious, organized, dependable, cooperative, flexible, trustful, and thorough. The personality facets are assessed as continuous variables ranging from one to five, with five indicating the highest score in that personality facet (e.g. $5=$ most agreeable) and one indicating the lowest score (e.g. $1=$ least agreeable).

At the family-level, our predictors of selfemployment include millennials' parental (both mother and father) monitoring. Mother's monitoring and father's monitoring are two separate continuous variables which range from zero to sixteen $(0=$ least parental monitoring, $16=$ greater parental monitoring). Thus, the highest the score for each variable the greater the parental monitoring the millennials received.

Finally, at the contextual level, we investigated whether and how the location in which millennials grew up influenced their decision to become selfemployed before, during, and/or after the recession. Specifically, urban/rural is a binary variable with 1 if millennials grew up in an urban area and 0 if millennials grew up in a rural area. This was assessed in 1997, when they were between 13 and 17.

\subsection{Control variables}

Control variables in this study include combined race/ethnicity at the person-level, and household income at the family-level. The control variables were assessed in the first survey in 1997. Race/Ethnicity is a binary variable, where one indicates non-Black and non-Hispanic, and zero otherwise (i.e. based on original survey coding which did not explicitly classify white category). Household income is coded as the $\log$ of the millennial's household income in 1997. Since a variable for education was not available beyond high school education, this variable was not relevant to address the research question. We anticipate this missing control variable would not be problematic as prior research suggests that there is "no relationship between educational attainment and entrepreneurship." (p. 241) [13].

\section{Results}

Millennials are broadly classified as those individuals born between 1980 and 1995 ([64]; [83]). This study sought to understand predictors of selfemployment among early millennials, those born between 1980-1984, who are now active early-career workforce participants. Our results indicate that millennials who were satisfied with their early-career jobs (job satisfaction indicator was lagged a year prior) were more likely to become self-employed before the recession hit (years 2005-2006, millennials at age 21$26, \mathrm{p}<.05)$. This result is also consistent after the recession. In the years immediately after the recession (2010-2011), millennials who were satisfied with their early-career jobs were more likely to engage in selfemployment (millennials at age 26-31, p<.01). During the recession, however, our indicator of job satisfaction is non-significant, although the coefficient indicates an inverse relationship.

Results regarding millennials' personality indicators suggest that being a conscientious individual decreased the likelihood of the millennial becoming self-employed during the recession (years 2007-2009, millennials at age 23-29, $\mathrm{p}<.05$ ). In addition, at the parental level, millennials who experienced higher father monitoring during adolescence were also less likely to become selfemployed during the recession $(\mathrm{p}<.01)$.

In order to further understand millennials' likelihood to become self-employed, we analyzed our dataset in subsamples by gender. Our subsample for female millennials indicates that experiencing earlycareer job satisfaction $(\mathrm{p}<.10)$ and being a flexible individual (as a personality trait) increased the likelihood of female millennials to become selfemployed in the years before the recession (millennials at age 21-26, years 2005-2006, p<.05). Furthermore, female millennials who experienced higher father monitoring during adolescence were less likely to become self-employed during the recession (years 2007-2009, millennials at age 23-29, $\mathrm{p}<.01$ ). 
Table 1. Predictors of self-employment among millennials before, during, and after the recession

\begin{tabular}{|c|c|c|c|}
\hline & $\begin{array}{c}\text { Before recession } \\
(2005-2006) \\
(\text { age } 21-26)\end{array}$ & $\begin{array}{c}\text { During recession } \\
(2007-2009) \\
\text { (age 23-29) }\end{array}$ & $\begin{array}{c}\text { After recession } \\
(2010-2011) \\
(\text { age } 26-31)\end{array}$ \\
\hline Gender $($ female $=1)$ & $\begin{array}{l}0.0207 \\
(0.205)\end{array}$ & $\begin{array}{l}-0.229 \\
(0.176)\end{array}$ & $\begin{array}{l}-0.155 \\
(0.178)\end{array}$ \\
\hline Rural (rural $=1$ ) & $\begin{array}{l}-0.212 \\
(0.232)\end{array}$ & $\begin{array}{l}-0.245 \\
(0.204)\end{array}$ & $\begin{array}{l}-0.0175 \\
(0.198)\end{array}$ \\
\hline Race $($ black or hispanic $=1)$ & $\begin{array}{l}-0.175 \\
(0.227)\end{array}$ & $\begin{array}{c}0.206 \\
(0.188)\end{array}$ & $\begin{array}{l}-0.272 \\
(0.199)\end{array}$ \\
\hline LogHHincome & $\begin{array}{l}-0.0731 \\
(0.0985)\end{array}$ & $\begin{array}{c}0.172 \\
(0.108)\end{array}$ & $\begin{array}{l}0.0683 \\
(0.116)\end{array}$ \\
\hline $\begin{array}{l}\text { Job satisfaction lagged (one } \\
\text { year prior to each period) }\end{array}$ & $0.260^{* * *}$ & -0.146 & $0.294^{* * * *}$ \\
\hline Organized & $\begin{array}{l}(0.117) \\
-0.0234 \\
(0.105)\end{array}$ & $\begin{array}{l}(0.0915) \\
-0.0473 \\
(0.0915)\end{array}$ & $\begin{array}{c}(0.102) \\
\mathbf{- 0 . 2 1 3}^{* * *} \\
(0.0932)\end{array}$ \\
\hline Concientious & $\begin{array}{l}-0.0411 \\
(0.0952)\end{array}$ & $\begin{array}{l}-\mathbf{0 . 2 0 9} * * \\
(0.0831)\end{array}$ & $\begin{array}{l}-0.0126 \\
(0.0876)\end{array}$ \\
\hline Dependable & $\begin{array}{l}0.0598 \\
(0.113)\end{array}$ & $\begin{array}{l}-0.0365 \\
(0.109)\end{array}$ & $\begin{array}{l}-0.127 \\
(0.104)\end{array}$ \\
\hline Thorough & $\begin{array}{l}0.0967 \\
(0.123)\end{array}$ & $\begin{array}{c}0.104 \\
(0.105)\end{array}$ & $\begin{array}{c}0.188 \\
(0.119)\end{array}$ \\
\hline Agreeable & $\begin{array}{l}-0.0181 \\
(0.112)\end{array}$ & $\begin{array}{c}0.0654 \\
(0.0996)\end{array}$ & $\begin{array}{l}0.202 * \\
(0.105)\end{array}$ \\
\hline Cooperative & $\begin{array}{l}-\mathbf{0 . 2 1 5} \\
(0.110)\end{array}$ & $\begin{array}{l}-0.153 \\
(0.104)\end{array}$ & $\begin{array}{l}-\mathbf{0 . 1 8 7 *} \\
(0.103)\end{array}$ \\
\hline Flexible & $\begin{array}{c}0.142 \\
(0.103)\end{array}$ & $\begin{array}{c}0.111 \\
(0.0910)\end{array}$ & $\begin{array}{c}0.0954 \\
(0.0877)\end{array}$ \\
\hline Trustful & $\begin{array}{l}-0.103 \\
(0.105)\end{array}$ & $\begin{array}{l}-0.0317 \\
(0.110)\end{array}$ & $\begin{array}{l}-0.0723 \\
(0.109)\end{array}$ \\
\hline Mother monitoring & $\begin{array}{c}0.0192 \\
(0.0419)\end{array}$ & $\begin{array}{c}0.0569 \\
(0.0375)\end{array}$ & $\begin{array}{l}-0.00876 \\
(0.0372)\end{array}$ \\
\hline Father monitoring & $\begin{array}{l}-0.0368 \\
(0.0313)\end{array}$ & $\begin{array}{c}-\mathbf{0 . 0 8 5 5} * k * k \\
(0.0298)\end{array}$ & $\begin{array}{l}-0.0197 \\
(0.0289)\end{array}$ \\
\hline Intercept & $\begin{array}{l}-2.303 \\
(1.429)\end{array}$ & $\begin{array}{c}-3.109 * * \\
(1.361)\end{array}$ & $\begin{array}{c}-3.774 * * * \\
(1.412)\end{array}$ \\
\hline $\mathrm{N}$ & 1,633 & 1,736 & 1,741 \\
\hline Wald chi2 & 16.66 & 30.68 & 37.63 \\
\hline Pseudo R-sq & 0.019 & 0.028 & 0.034 \\
\hline Prob $>$ chi 2 & 0.339 & 0.01 & 0.001 \\
\hline
\end{tabular}

Our subsample for male millennials indicates that experiencing higher early-career job satisfaction $(p<.01)$ and being agreeable $(p<.05)$ increased the likelihood of male millennials to become selfemployed in the years after the recession (millennials at age 26-31, years 2010-2011). On the other hand, male millennials who are organized and dependable (as personality traits) were less likely to become selfemployed in the years after the recession $(\mathrm{p}<.05$ and $\mathrm{p}<.01$ respectively). During the recession (years 20072009), male millennials who were conscientious were less likely to become self-employed $(\mathrm{p}<.01)$. Overall, our indicators denote dissimilar results between male and female subsamples.

Our predictors of self-employment among millennials by location indicate that millennials who grew up in a rural area and who were satisfied with their early-career job in 2009 were more likely to engage in self-employment after the recession (20102011, millennials at age $26-31, p<.01$ ). In addition, millennials who grew up in a rural area and are conscientious (as a personality trait) were less likely to engage in self-employment before the recession (2005-2006, millennials at age 21-26, p<.05) and during the recession (2007-2009, millennials at age
23-29, $\mathrm{p}<.01$ ). A millennial who is organized (as a personality trait) were also less likely to engage in selfemployment after the recession (2010-2011, millennials at age 26-31, $\mathrm{p}<.05$ ).

\section{Table 2. Predictors of self-employment among millennials by gender}

\begin{tabular}{|c|c|c|c|c|c|c|}
\hline & \multicolumn{3}{|c|}{ FEMALE ONLY } & \multicolumn{3}{|c|}{ MALE ONLY } \\
\hline & $\begin{array}{l}\text { Before recession } \\
(2005-2006) \\
(\text { age 21-26) }\end{array}$ & $\begin{array}{c}\text { During recession } \\
(2007-2009) \\
(\text { age 23-29) }\end{array}$ & $\begin{array}{l}\text { After recession } \\
(2010-2011) \\
(\text { age 26-31) }\end{array}$ & $\begin{array}{c}\text { Before recession } \\
(2005-2006) \\
(\text { age } 21-26)\end{array}$ & $\begin{array}{c}\text { During recession } \\
\text { (2007-2009) } \\
\text { (age 23-29) }\end{array}$ & $\begin{array}{c}\text { After recession } \\
\text { (2010-2011) } \\
\text { (age 26-31) }\end{array}$ \\
\hline Rural (rural = 1) & -0.306 & -0.296 & 0.277 & -0.149 & -0.249 & -0.183 \\
\hline & $(0.365)$ & $(0.335)$ & $(0.318)$ & $(0.302)$ & $(0.257)$ & $(0.259)$ \\
\hline Race $($ black or hispanic $=1$ ) & -0.0720 & $\begin{array}{c}0.106 \\
(0.278)\end{array}$ & $\begin{array}{c}-0.133 \\
(0.301)\end{array}$ & $\begin{array}{c}-0.268 \\
(0.339)\end{array}$ & $\begin{array}{c}0.283 \\
(0.260)\end{array}$ & $\begin{array}{c}-0.366 \\
(0.273)\end{array}$ \\
\hline LogHHincome & $\begin{array}{c}-0.115 \\
(0.126)\end{array}$ & $\begin{array}{c}0.230 \\
(0.198)\end{array}$ & $\begin{array}{l}0.0977 \\
(0.189)\end{array}$ & $\begin{array}{r}-0.0565 \\
(0.148)\end{array}$ & $\begin{array}{c}0.126 \\
(0.128)\end{array}$ & $\begin{array}{l}0.0404 \\
(0.150)\end{array}$ \\
\hline $\begin{array}{l}\text { Job satisfaction lagged (one } \\
\text { year prior to each period) }\end{array}$ & $0.317^{*}$ & -0.177 & 0.167 & 0.225 & -0.120 & $0.419^{* * k *}$ \\
\hline & $(0.172)$ & $(0.116)$ & $(0.138)$ & $(0.157)$ & $(0.138)$ & $(0.153)$ \\
\hline Organized & $\begin{array}{l}0.0392 \\
(0.154)\end{array}$ & $\begin{array}{l}0.0760 \\
(0.150)\end{array}$ & $\begin{array}{l}-0.167 \\
(0.144)\end{array}$ & $\begin{array}{l}-0.0888 \\
(0.144)\end{array}$ & $\begin{array}{l}-0.140 \\
(0.115)\end{array}$ & $\begin{array}{c}-0.239 * * \\
(0.122)\end{array}$ \\
\hline Concientious & $\begin{array}{l}0.0587 \\
(0.130)\end{array}$ & $\begin{array}{l}-0.0838 \\
(0.127)\end{array}$ & $\begin{array}{l}0.0368 \\
(0.141)\end{array}$ & $\begin{array}{r}-0.136 \\
(0.138)\end{array}$ & 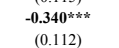 & $\begin{array}{l}-0.0870 \\
(0.116)\end{array}$ \\
\hline Dependable & $\begin{array}{l}0.0534 \\
(0.173)\end{array}$ & $\begin{array}{l}0.0493 \\
(0.173)\end{array}$ & $\begin{array}{c}0.251 \\
(0.236)\end{array}$ & $\begin{array}{l}0.0731 \\
(0.152)\end{array}$ & $\begin{array}{l}-0.103 \\
(0.142)\end{array}$ & 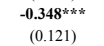 \\
\hline Thorough & $\begin{array}{c}0.135 \\
(0.171)\end{array}$ & $\begin{array}{l}0.0589 \\
(0.156)\end{array}$ & $\begin{array}{c}0.225 \\
(0.190)\end{array}$ & $\begin{array}{l}0.0605 \\
(0.176)\end{array}$ & $\begin{array}{c}0.136 \\
(0.142)\end{array}$ & $\begin{array}{c}0.151 \\
(0.151)\end{array}$ \\
\hline Agreeable & $\begin{array}{c}-0.0594 \\
(0.187)\end{array}$ & $\begin{array}{l}0.0351 \\
(0.163)\end{array}$ & $\begin{array}{l}0.0993 \\
(0.187)\end{array}$ & $\begin{array}{c}-0.00793 \\
(0.141)\end{array}$ & $\begin{array}{l}0.0833 \\
(0.129)\end{array}$ & $\begin{array}{l}\mathbf{0 . 2 6 5 ^ { * * }} \\
(0.122)\end{array}$ \\
\hline Cooperative & $\begin{array}{c}-0.182 \\
(0.166)\end{array}$ & $\begin{array}{l}-0.122 \\
(0.172)\end{array}$ & $\begin{array}{l}-0.262 \\
(0.167)\end{array}$ & $\begin{array}{l}-0.227 \\
(0.149)\end{array}$ & $\begin{array}{l}-0.165 \\
(0.126)\end{array}$ & $\begin{array}{l}-0.105 \\
(0.128)\end{array}$ \\
\hline Flexible & $\begin{array}{l}\mathbf{0 . 2 9 0 ^ { * * k }} \\
(0.139)\end{array}$ & $\begin{array}{l}0.0920 \\
(0.141)\end{array}$ & $\begin{array}{c}0.122 \\
(0.131)\end{array}$ & $\begin{array}{c}-0.00501 \\
(0.148)\end{array}$ & $\begin{array}{c}0.135 \\
(0.119)\end{array}$ & $\begin{array}{l}0.0746 \\
(0.121)\end{array}$ \\
\hline Trustful & $\begin{array}{l}-0.0622 \\
(0.163)\end{array}$ & $\begin{array}{c}-0.162 \\
(0.171)\end{array}$ & $\begin{array}{l}-0.231 \\
(0.164)\end{array}$ & $\begin{array}{l}-0.103 \\
(0.138)\end{array}$ & $\begin{array}{l}0.0690 \\
(0.148)\end{array}$ & $\begin{array}{l}0.0906 \\
(0.146)\end{array}$ \\
\hline Mother monitoring & $\begin{array}{c}0.0592 \\
(0.0640)\end{array}$ & $\begin{array}{c}0.0749 \\
(0.0583)\end{array}$ & $\begin{array}{c}0.0196 \\
(0.0636)\end{array}$ & $\begin{array}{l}0.000499 \\
(0.0592)\end{array}$ & $\begin{array}{c}0.0377 \\
(0.0500)\end{array}$ & $\begin{array}{c}-0.0472 \\
(0.0481)\end{array}$ \\
\hline Father monitoring & $\begin{array}{c}-0.0601 \\
(0.0451)\end{array}$ & $\begin{array}{l}-0.124^{* k * k} \\
(0.0412)\end{array}$ & $\begin{array}{c}-0.0474 \\
(0.0425)\end{array}$ & $\begin{array}{l}-0.0236 \\
(0.0451)\end{array}$ & $\begin{array}{l}-0.0539 \\
(0.0431)\end{array}$ & $\begin{array}{l}0.00705 \\
0.0393)\end{array}$ \\
\hline Intercept & $\begin{array}{l}-3.469^{*} \\
(1.835)\end{array}$ & $\begin{array}{l}-3.988^{*} \\
(2.384)\end{array}$ & $\begin{array}{l}-4.427^{*} \\
(2.379)\end{array}$ & $\begin{array}{l}-1.330 \\
(2.173)\end{array}$ & $\begin{array}{l}-2.566 \\
(1.742)\end{array}$ & $\begin{array}{c}-3.748^{* *} \\
(1.825)\end{array}$ \\
\hline $\mathrm{N}$ & 786 & 831 & 813 & 847 & 905 & 928 \\
\hline Wald chi2 & 15.03 & 20.95 & 17.34 & 14.05 & 22.09 & 37.59 \\
\hline Pseudo R-sq & 0.031 & 0.034 & 0.032 & 0.024 & 0.035 & 0.059 \\
\hline Prob $>$ chi2 & 0.376 & 0.103 & 0.239 & 0.446 & 0.077 & 0.001 \\
\hline
\end{tabular}

\section{Table 3. Predictors of self-employment among millennials by location}

\begin{tabular}{|c|c|c|c|c|c|c|}
\hline & \multicolumn{3}{|c|}{\begin{tabular}{c|} 
GREW UP IN RURAL \\
\end{tabular}} & \multicolumn{3}{|c|}{ GREW UP IN URBAN } \\
\hline & $\begin{array}{l}\text { Before recession } \\
\text { (2005-2006) } \\
\text { (age 21-26) }\end{array}$ & $\begin{array}{c}\text { During recession } \\
(2007-2009) \\
\text { (age 23-29) }\end{array}$ & $\begin{array}{l}\text { After recession } \\
(2010-2011) \\
\text { (age 26-31) }\end{array}$ & $\begin{array}{l}\text { Before recession } \\
(2005-2006)\end{array}$ & $\begin{array}{l}\text { During recession } \\
(2007-2009)\end{array}$ & $\begin{array}{c}\text { After recession } \\
\text { (2010-2011) } \\
\text { (age 26-31) }\end{array}$ \\
\hline Gender $($ female $=1)$ & -0.0229 & -0.210 & 0.257 & 0.0295 & -0.259 & -0.256 \\
\hline & $(0.384)$ & $(0.327)$ & $(0.333)$ & $(0.240)$ & $(0.201)$ & $(0.207)$ \\
\hline Race $($ black or hispanic $=1$ ) & -0.448 & 0.256 & -0.321 & -0.00884 & 0.243 & -0.204 \\
\hline & $(0.594)$ & $(0.395)$ & $(0.442)$ & $(0.245)$ & $(0.208)$ & $(0.219)$ \\
\hline LogHHincome & -0.0585 & 0.257 & 0.281 & -0.0140 & 0.131 & 0.0423 \\
\hline & $(0.259)$ & $(0.265)$ & $(0.246)$ & $(0.121)$ & $(0.109)$ & $(0.116)$ \\
\hline $\begin{array}{l}\text { Job satisfaction lagged (one } \\
\text { year prior to each period) }\end{array}$ & 0.0683 & -0.189 & $0.777^{* k \cdots k}$ & $0.440^{* k * k}$ & -0.129 & 0.153 \\
\hline & $(0.220)$ & $(0.199)$ & $(0.218)$ & $(0.147)$ & (0.0939) & $(0.108)$ \\
\hline Organized & $\begin{array}{c}0.104 \\
(0.263)\end{array}$ & $\begin{array}{l}-0.0406 \\
(0.195)\end{array}$ & 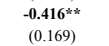 & $\begin{array}{l}-0.108 \\
(0.112)\end{array}$ & $\begin{array}{c}-0.0778 \\
(0.0965)\end{array}$ & $\begin{array}{l}-0.158 \\
(0.103)\end{array}$ \\
\hline Concientious & $\begin{array}{c}-0.404^{* * k} \\
(0.201)\end{array}$ & $\begin{array}{c}-0.522^{* * * *} \\
(0.167)\end{array}$ & $\begin{array}{l}-0.123 \\
(0.175)\end{array}$ & $\begin{array}{l}0.0683 \\
(0.108)\end{array}$ & $\begin{array}{c}-0.0832 \\
(0.0892)\end{array}$ & $\begin{array}{c}0.0275 \\
(0.0961)\end{array}$ \\
\hline Dependable & -0.0811 & -0.0632 & 0.166 & $\begin{array}{l}0.0785 \\
0.124)\end{array}$ & -0.0261 & $\begin{array}{l}-0.159 \\
(0.112)\end{array}$ \\
\hline Thorough & $\begin{array}{c}0.204 \\
(0.227)\end{array}$ & $\begin{array}{c}0.178 \\
(0.169)\end{array}$ & $\begin{array}{l}0.0942 \\
(0.191)\end{array}$ & $\begin{array}{c}-0.00754 \\
(0.135)\end{array}$ & $\begin{array}{l}0.0945 \\
(0.118)\end{array}$ & $\begin{array}{l}0.126 \\
(0.130)\end{array}$ \\
\hline Agreeable & $\begin{array}{c}-0.223 \\
(0.215)\end{array}$ & $\begin{array}{l}-0.165 \\
(0.153)\end{array}$ & $\begin{array}{l}0.0543 \\
(0.173)\end{array}$ & $\begin{array}{l}-0.0355 \\
(0.131)\end{array}$ & $\begin{array}{l}0.0423 \\
(0.113)\end{array}$ & $\begin{array}{c}0.194 \\
(0.123)\end{array}$ \\
\hline Cooperative & $\begin{array}{c}-0.292 \\
(0.211)\end{array}$ & $\begin{array}{c}-0.128 \\
(0.176)\end{array}$ & $\begin{array}{c}-0.261 \\
(0.177)\end{array}$ & $\begin{array}{c}-0.172 \\
(0.123)\end{array}$ & $\begin{array}{l}-0.115 \\
(0.111)\end{array}$ & $\begin{array}{l}-0.150 \\
(0.116)\end{array}$ \\
\hline Flexible & $\begin{array}{c}-0.00338 \\
(0.198)\end{array}$ & $\begin{array}{l}-0.132 \\
(0.169)\end{array}$ & $\begin{array}{l}-0.100 \\
(0.152)\end{array}$ & $\begin{array}{c}0.189 \\
0.118)\end{array}$ & $\begin{array}{c}0.124 \\
(0.0955)\end{array}$ & $\begin{array}{c}0.154 \\
(0.0999)\end{array}$ \\
\hline Trustful & $\begin{array}{l}(0.198) \\
-0.0786 \\
(0.226)\end{array}$ & $\begin{array}{l}(0.109) \\
-0.0817 \\
(0.203)\end{array}$ & $\begin{array}{l}(0.152) \\
-0.0589 \\
(0.208)\end{array}$ & $\begin{array}{l}(0.118) \\
0.0297 \\
(0.123)\end{array}$ & $\begin{array}{c}(0.0953) \\
0.0365 \\
(0.117)\end{array}$ & $\begin{array}{l}(0.0999) \\
-0.0206 \\
(0.121)\end{array}$ \\
\hline Mother monitoring & $\begin{array}{l}0.00995 \\
(0.0775)\end{array}$ & $\begin{array}{c}(0.20415 \\
0.0415 \\
(0.0754)\end{array}$ & $\begin{array}{l}(0.200539) \\
0.00599)\end{array}$ & $\begin{array}{l}0.10465 \\
0.0465 \\
(0.0460)\end{array}$ & $\begin{array}{l}0.0647^{*} \\
(0.0391)\end{array}$ & $\begin{array}{l}0.10120 \\
(0.0401)\end{array}$ \\
\hline Father monitoring & $\begin{array}{c}-0.0349 \\
(0.0674)\end{array}$ & $\begin{array}{l}-0.0291 \\
(0.0574)\end{array}$ & $\begin{array}{c}-0.0279 \\
(0.0543)\end{array}$ & $\begin{array}{c}-0.0741^{* * *} \\
(0.0339)\end{array}$ & 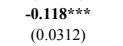 & $\begin{array}{c}-0.0143 \\
(0.0307)\end{array}$ \\
\hline Intercept & $\begin{array}{c}0.299 \\
(3.413)\end{array}$ & $\begin{array}{l}-2.058 \\
(3.118)\end{array}$ & $\begin{array}{c}-6.912^{* * *} \\
(2.881)\end{array}$ & $\begin{array}{c}-4.368^{* * *} \\
(1.720)\end{array}$ & $\begin{array}{c}-3.219^{* * *} \\
(1.405)\end{array}$ & $\begin{array}{c}-3.395 * * \\
(1.478)\end{array}$ \\
\hline $\mathrm{N}$ & 555 & 563 & 573 & 1230 & 1331 & 1334 \\
\hline Wald chi2 2 & 20.29 & 19.42 & 34.5 & 19.04 & 23.36 & 25.22 \\
\hline Pseudo R-sq & 0.053 & 0.061 & 0.099 & 0.033 & 0.029 & 0.025 \\
\hline Prob $>$ chi2 & 0.121 & 0.149 & 0.002 & 0.163 & 0.055 & 0.033 \\
\hline
\end{tabular}


Among millennials who grew up in an urban area, those who were satisfied with their early career job in 2004, were more likely to engage in self-employment before the recession (2005-2006, millennials at age $21-26, \mathrm{p}<.01)$. In addition, higher father monitoring during the millennial's adolescence years for those who grew up in an urban area decreased the likelihood that the millennial would engage in self-employment before the recession (2005-2006, millennials at age $21-26, \mathrm{p}<.05)$ and also during the recession (20072009 , millennials at age $23-29, \mathrm{p}<.01$ ).

\section{Discussion}

Research on millennials in the digital economy, and in the workforce in general, remains vastly understudied and misunderstood; most of the research to date has focused on millennials during adolescence years [21]. Nonetheless, the limited research available emphasizes that millennials exhibit different career goals and expectations than other prior generations ([64]; [79]). For instance, millennials tend to have more difficulties staying in the same job, potentially leading them to seek self-employment as an alternative option to find flexibility and meaning at work. Others are still living with their parents ([7]; [72]), which further influences their career options and differentiates them from the gen $\mathrm{X}$ and baby boomers' relatively more stable career paths. This study sought to understand what characteristics or predictors influenced early millennials (i.e. those born between 1980 and 1984) to pursue self-employment in recent years, which coincides with their early-career path.

Overall, regarding the effect of early-career job satisfaction among early millennials, our results indicate that female millennials and those who grew up in an urban area, who were satisfied with their early-career job (at age 20-25), were more likely to become self-employed in the years before the recession started (2005-2006, between ages 21 and 26). After the recession, however, male millennials and those who grew up in a rural area were more likely to engage in self-employment (2010-2011, between ages 26 and 31). This comparative finding suggests that early-career job satisfaction among female millennials and those who grew up in an urban area positively contributes to the decision to become selfemployed in their early 20's, whereas for male millennials and those who grew up in a rural area, the decision to become self-employed which is driven by job satisfaction arrives in their late 20's and very early 30's (ages 26-31). No significant results were observed during the recession years.

Regarding the father's parental monitoring, our findings for female millennials indicate that higher monitoring from the father during adolescence, negatively influenced their likelihood to choose selfemployment during the recession. Among early millennials who grew up in an urban area, higher father's monitoring during adolescence decreased their likelihood to choose self-employment altogether in the years before the recession and during the recession (between ages 21-29). As such, it appears that millennials' upbringing might have a longerlasting influence on their choice to choose selfemployment as an alternative career path, especially among women and those who grew up in an urban area, in contrast to the effects of their individual earlycareer job satisfaction. The overall results regarding the influence of parental monitoring further suggest that higher autonomy when growing up is a positive predictor of millennials' self-employment decision in their early-career stage, especially among women and those who grew up in an urban area. This is consistent with research on millennials [63], as well as with research on predictors of self-employment ([6]; [54]).

Furthermore, our results for the personality facets (controls for variation in personality traits) suggest more nuanced findings than prior research offers, especially for millennials. We find that, overall for all early millennials, higher levels of conscientiousness lead to lower levels of self-employment activity during the recession years (2007-2009, millennials at age 2329 ), which runs counter to prior research. This is particularly observed among millennials who grew up in a rural area and among male millennials. Indeed, conscientiousness is one of the Big Five traits which has been shown to predict self-employment and entrepreneurial intentions [84]. Nevertheless, millennials are different from previous generations ([23]; [78]), and millennials with higher conscientiousness might not be willing to take the risk to venture into self-employment early in their career (between ages 23-29). This is also consistent with the idea that lower levels of conscientiousness are related to higher risk propensity [65], which in turn is positively related to higher levels of self-employment ([27]; [28]). Finally, being organized (as a personality trait) also predicts lower levels of self-employment among millennials in the years after the recession (2010-11, at age between 26 and 31), especially men and those who grew up in a rural area.

\subsection{Limitations}

In order to rule out potential reverse causality, our study uses all years available for millennials' earlycareer stage, covering the entire spectrum between age 21 and age 31. Also, our study uses a one-year lag for each time period (before the recession, during, after) for job satisfaction, that is intended to capture the 
effect of prior job satisfaction in the likelihood to become self-employed among early-career millennials. Nonetheless, our data limited our ability to examine re-entry into wage employment, after a certain period of self-employment. As longitudinal data on millennials in the workforce evolves, future research could investigate not only predictors of selfemployment among millennials, but also predictors of re-entry into wage-employment, and incidentally whether self-employment-related skills further contributed to enhanced career outcomes (e.g. increased job satisfaction, work-life balance, flexibility, salary). Such studies would be consistent with prior research which finds evidence of positive effects of self-employment on re-entry into the workplace [16].

A second limitation of our study is that our database does not offer self-reported indicators of motives to engage in self-employment. Future research could conduct field studies focusing on the motives among millennials to become and remain selfemployed. For example, research suggests that two drivers of self-employment include higher independence and income ([28], p. 81), where the individual "chooses to become self-employed if the total utility they expect to derive (via income and independence) is greater than the expected utility from their best employment option." Those who become self-employed make about three times the earnings of wage employees [74]. Understanding the actual motives that lead the millennial to engage in selfemployment at a point in time could further shed light on the drivers of self-employment for this generation.

\section{Conclusion}

Millennials' expectations and attitudes towards the workplace -meaningful jobs, supportive and flexible environment, work-life balance, and high pay - differ from current generations. The current lifestage of the first millennials in the present workforce positioned this study in a timely and salient opportunity to delve into the practical underpinnings of millennial's work expectations and current realities in the workplace. At this stage, values and attitudes towards work are considered the most stable and least likely to change, compared to surveys conducted during their adolescence life-stage. In this framework, our study sought to unveil predictors of selfemployment among millennials in the years before the recession, during the recession, and after the recession, which coincide with their early career stage (between age 21 and 31 ).

Our results suggest that female millennials and millennials who grew up in an urban area were more likely to become self-employed in their early twenties, whereas male millennials and those who grew up in a rural area were more likely to become self-employed in their late twenties and very early thirties. Regarding the impact of parental monitoring, we find that higher monitoring by the father during adolescence negatively influenced the likelihood of becoming selfemployed in their mid-twenties (during the recession) among female millennials and millennials who grew up in an urban area. Regarding the role of how personality facets differ among female and male millennials and between those who grew up in an urban or rural area, our results suggest that being more conscientious, especially among male millennials and those who grew up in a rural area, led to a lower likelihood of becoming self-employed during their mid-twenties (millennials between age 23 and 29), which coincides with the recession years (2007-2009).

\section{References}

[1] Amit, R. H., MacCrimmon, K. R., \& Zietsma, C. (2000). Does money matter? Wealth attainment as the motive for initiating growth-oriented technology ventures. Journal of Business Venturing, 16, 119-143.

[2] Andersson, P. (2008). Happiness and health: Well-being among the self-employed. Journal of Socio-Economics, 37, 213-236.

[3] Baiyun, G., Ramkissoon, A., Greenwood, R., \& Hoyte, D.S. (2018). The generation for change: Millennials, their career orientation, and role innovation. Journal of Managerial Issues, 30(1), 82-96.

[4] Baron, R. A., Franklin, R. J., \& Hmieleski, K. M. (2016). Why entrepreneurs often experience low, not high, levels of stress: The joint effects of selection and psychological capital. Journal of Management, 42, 742-768.

[5] Behrstock-Sherratt, E. and Coggshall, J.G. (2010), "Realizing the promise of generation Y", Educational Leadership, Vol. 67 No. 8, pp. 28-34.

[6] Benz, M., \& Frey, B. S. (2008). The value of doing what you like: Evidence from the self-employed. Journal of Economic Behavior \& Organization, 68, 445-455.

[7] Berridge, S. (2014). Millennials after the Great Recession. Monthly Labor Review, Bureau of Labor Statistics. Retrieved 31 July 2017 from: https://www.bls.gov/opub/mlr/2014/beyond-

bls/pdf/millennials-after-the-great-recession.pdf

[8] Binder, M., \& Coad, A. (2013). Life satisfaction and selfemployment: A matching approach. Small Business Economics, 40, 1009-1033.

[9] Bird, B. (1989). Entrepreneurial Behavior. Glenview and London: Scott, Foresman and Company.

[10] Bradley, D. E., \& Roberts, J. A. (2004). Selfemployment and job satisfaction. Journal of Small Business Management, 42, 37-58.

[11] Bradley-Geist, J. C., \& Olson-Buchanan, J. B. (2014). Helicopter parents: An examination of the correlates of overparenting. Education + Training, 56, 314-328.

[12] Broadbridge, A., Maxwell, G., \& Ogden, S. (2007). Experiences, perceptions and expectations of retail 
employment for Generation Y." Career Development International, 12(6), 523-544.

[13] Burton, M. D., Sorensen, J. B., \& Dobrev, S. D. (2016). A careers perspective on entrepreneurship. Entrepreneurship Theory and Practice, 40, 237-247.

[14] Cable, D. M., \& Judge, T. A. (1996). Personorganization fit, job choice decisions, and organizational entry. Organizational Behavior and Human Decision Processes, 67, 294-311.

[15] Caliendo, M., Fossen, F., \& Kritikos, A. S. (2014). Personality characteristics and the decisions to become and stay self-employed. Small Business Economics, 42, 787-814. [16] Carrasco, R. (1999). Transitions to and from selfemployment in Spain: An empirical analysis. Oxford Bulletin of Economics and Statistics, 61, 315-341.

[17] Cennamo, L., \& Gardner, D. (2008). Generational differences in work values, outcomes and personorganization values fit. Journal of Managerial Psychology, 23, 891-906.

[18] Chlosta, S., Patzelt, H., Klein, S. B., \& Dormann, C. (2012). Parental role models and the decision to become selfemployed: The moderating effect of personality. Small Business Economics, 38, 121-138.

[19] Clark, A., \& Oswald, A. (1996). Satisfaction and comparison income. Journal of Public Economics, 61, 359381.

[20] Davis, A. E., \& Shaver, K. S. (2012). Understanding gendered variations in business growth intentions across the life course. Entrepreneurship Theory and Practice, 36, 495512.

[21] De Hauw, S., \& De Vos, A. (2010). Millennials' career perspective and psychological contract expectations. Journal of Business and Psychology, 25, 293-302.

[22] De Vos, A. \& Van der Heijden, B. I. J. M. (2015). Handbook of Research on Sustainable Careers. Cheltenam, UK: Edward Elgar Publishing.

[23] Deal, J. J., Altman, D. G., \& Rogelberg, S. G. (2010). Millennials at work: What we know and what we need to do. Journal of Business and Psychology, 25, 191-199.

[24] Dietrich, J., \& Kracke, B. (2009). Career-specific parental behaviors in adolescents' development. Journal of Vocational Behavior, 75, 109-119.

[25] Dishion, T. J., \& McMahon, R. J. (1998). Parental monitoring and the prevention of child and adolescent problem behavior: A conceptual and empirical formulation. Clinical Child and Family Psychology Review, 1, 61-75.

[26] Dolan, P., Peasgood, T., \& White, M. (2008). Do we really know what makes us happy? A review of the economic literature of the factors associated with subjective well-being. Journal of Economic Psychology, 29, 94-122.

[27] Douglas, E. J., \& Shepherd, D. A. (2000). Entrepreneurship as a utility- maximizing response. Journal of Business Venturing, 15, 231-252.

[28] Douglas, E. J., \& Shepherd, D. A. (2002). Selfemployment as a Career Choice. Entrepreneurial Theory and Practice, 26, 81-90.

[29] Dries, N., Pepermans, R., \& Kerpel, E. (2008). Exploring four generations' beliefs about career. Journal of Managerial Psychology, 23(8), 907-928.

[30] Dyer, W. G. (1994). Toward a theory of entrepreneurial careers. Entrepreneurship Theory and Practice, 19, 7-22.

[31] Earle, J. S., \& Sakova, Z. (2000). Business start-ups or disguised unemployment? Labour Economics, 7, 575-601. [32] Failla, V., Melillo, F., \& Reichstein, T. (2017). Entrepreneurship and employment stability - Job matching, labour market value, and personal commitment. Journal of Business Venturing, 32, 162-177.

[33] Feldman, D. C., \& Bolino, M. C. (2000). Career patterns of the self-employed. Journal of Small Business Management, 38, 53-67.

[34] Foster, K. (2012). Youth unemployment and un(der) employment in Canada: More than a temporary problem? Ottawa: Canadian Centre for Policy Alternatives. [35] Guerra, G., \& Patuelli, R. (2016). The role of job satisfaction in transitions into selfemployment. Entrepreneurship Theory \& Practice, 40, 543571.

[36] Hamilton, B. H., (2000). Does entrepreneurship pay? An empirical analysis of the returns to self-employment. Journal of Political Economy, 108, 604-631.

[37] Hershatter, A., \& Epstein, M. (2010). Millennials and the world of work. Journal of Business and Psychology, 25(2), 211-223.

[38] Howe, N., \& Strauss, W. (2000). Millennials rising: The next great generation. New York: Random House LLC. [39] Huws, U. (2014). Labor in the global digital economy: The cybertariat comes of age. New York, NY: NYU Press. [40] ILO (2013). Global employment trends for youth 2013: A generation at risk. Geneva: International Labour Office. [41] Jackson, C.K. (2013). Match quality, worker productivity, and worker mobility: direct evidence from teachers. Review of Economic Statistics, 95, 1096-1116.

[42] Jin, J., \& Rounds, J. (2012). Stability and change in work values: a meta-analysis of longitudinal studies. Journal of Vocational Behavior, 80(2), 326-339.

[43] Jodl, K. M., Michael, A., Malanchuk, O., Eccles, J. S., \& Sameroff, A. (2001). Parents' roles in shaping early adolescents' occupational aspirations. Child Development, 72, 1247-1266.

[44] Johnson, M., \& Johnson, L. (2010), Generations, Inc. AMACOM, New York, NY.

[45] Joona, P., \& Wadensjö, E. (2013). The best and the brightest or the least successful? Small Business Economics, 40, 155-172.

[46] Kaiser, U., \& Malchow-Moller, N. (2011). Is selfemployment really a bad experience? Journal of Business Venturing, 26, 572-588.

[47] Katz, J. A. (1994). Modeling entrepreneurial career progressions: Concepts and considerations. Entrepreneurship Theory and Practice, 19, 23-40.

[48] Knight, F. H. (1921). Risk, Uncertainty, and Profit. New York: Houghton Mifflin Company.

[49] Kolvereid, L. (1996). Organizational employment versus self-employment. Entrepreneurship Theory and Practice, 20, 23-31.

[50] Krahn, H.J., \& Galambos, N.L. (2014). Work values and beliefs of 'Generation X' and 'Generation Y'. Journal of Youth Studies, 17(1), 92-112.

[51] Kristof, A. L. (1996). Person-organization fit: An integrative review of its conceptualizations, measurement, and implications. Personnel Psychology, 49, $1-49$.

[52] Kultalahti, S., \& Viitala, R. (2015). Generation Y Challenging clients for HRM? Journal of Managerial Psychology, 30, 101-114. 
[53] Kuron, L., Lyons, S., Schweitzer, L., \& Ng, E.S.W. (2015). Millennial's work values. Personnel Review, 44(6), 991-1009.

[54] Lange, T. (2012). Job satisfaction and self-employment. Small Business Economics, 38, 165-177.

[55] Lyons, S., Duxbury, L., \& Higgins, C. (2007). An empirical assessment of generational differences in basic human values. Psychological Reports, 101(2), 339-352.

[56] Manso, G. (2016). Experimentation and the Returns to Entrepreneurship. The Review of Financial Studies, 29, 2319-2340.

[57] Markman, G., \& Baron, R. (2003). Personentrepreneurship fit: Why some people are more successful. Human Resource Management Review, 13, 281-301.

[58] Marshall, V.W., \& Wells, A.L. (2013). Generational relations and the workplace: a critique of the concept. In Taylor, P. (Ed), Older Workers in an Ageing Society: Critical Topics in Research and Policy, Edward Elgar, Northampton, MA, pp. 179-201.

[59] Martin, C.A. (2005). From high maintenance to high productivity. Industrial and Commercial Training, 37(1), 39-44.

[60] McGinnis Johnson, J., \& Ng, E.S. (2016). Money talks or millennials walk. Review of Public Personnel Administration, 36(3), 283-305.

[61] Millán, J.M., Hessels, J., Thurik, R., \& Aguado, R. (2013). Determinants of job satisfaction. Small Business Economics, 40, 651-670.

[62] Mungai, E., \& Velamuri, S. R. (2011). Parental entrepreneurial role model influence on male offspring. Entrepreneurship Theory and Practice, 35, 337-357.

[63] Myers, K. K., \& Sadaghiani, K. (2010). Millennials in the workplace. Journal of Business and Psychology, 25, 225238.

[64] Ng, E.S.W., Schweitzer, L. \& Lyons, S.T. (2010). New generation, great expectations: millennial generation. Journal of Business and Psychology, 25(2), 281-292.

[65] Nicholson, N., Soane, E., Fenton-O'Creevy, M., \& Willman, P. (2005). Personality and domain-specific risk taking. Journal of Risk Research, 8, 157-176.

[66] Noorderhaven, N., Thurik, R., Wennekers, S., \& van Stel, A. (2004). The role of dissatisfaction and per capita income in explaining self-employment. Entrepreneurship Theory and Practice, 28, 447-466.

[67] Odenweller, K. G., Booth-Butterfield, M., \& Weber, K. (2014). Investigating helicopter parenting, family environments, and relational outcomes for millennials. Communication Studies, 65, 407-425.

[68] Oreopoulos, P., Von Wachter, T., \& Heisz, A. (2012). The short-and long-term career effects of graduating in a recession. American Economic Journal: Applied Economics, 4, 1-29.

[69] Parasuraman, S., \& Simmers, C.A. (2001). Type of employment, work-family conflict and well-being. Journal of Organizational Behavior, 22, 551-568.

[70] Parker, S.C. (2009). The Economics of Entrepreneurship. Cambridge University Press, Cambridge. [71] Peters, P., Van der Heijden, B. I. J. M., Spurk, D., de Vos, A., \& Klaassen, R. (2017). Social dialogue as a sustainable career development practice to combat (meta)stereotyping. In A. Arenas, D. Di Marco, L. Munduate, \& M. Euwema (Eds.) Shaping Inclusive
Workplaces Through Social Dialogue. Industrial Relations \& Conflict Management. New York, NY: Springer.

[72] Rappaport, J. (2015). Millennials, baby boomers, and rebounding multifamily home construction. Federal Research Bank of Kansas City. Retrieved 31 July 2017.

[73] Rauch, A., \& Frese, M. (2014). Born to be an entrepreneur? Revisiting the personality approach to entrepreneurship. In J. R. Baum, M. Frese, \& R. A. Baron (Eds), The Psychology of Entrepreneurship (pp. 41-66). New York, NY: Taylor \& Francis.

[74] Rees, H., \& Shah, A. (1986). An empirical analysis of self-employment in the U.K. Journal of Applied Econometrics, 1, 95-108.

[75] Schmitt-Rodermund, E. (2004). Pathways to successful entrepreneurship. Journal of Vocational Behavior, 65, 498518.

[76] Solnet, D., \& Hood, A. (2008). Generation Y as hospitality employees: Framing a research agenda. Journal of Hospitality \& Tourism Management, 5(4), 59-68.

[77] Taylor, M. P. (1999). Survival of the fittest? The Economic Journal, 109, 140-155.

[78] Twenge, J. M., \& Campbell, S. M. (2012). Who are the Millennials? In E.S. Ng, S.T. Lyons, \& L. Schweitzer (Eds.), Managing the New Workforce: Millennial Generation (pp. 152-180). Cheltenham, UK: Edward Elgar.

[79] Twenge, J.M., Campbell, S.M., Hoffman, B.J., \& Lance, C.E. (2010). Generational differences in work values. Journal of Management, 36, 1117-1142.

[80] Twenge, J.M. (2006). Generation Me: Why Today's Young Americans are More Confident, Assertive, Entitled and More Miserable than Ever Before, Free Press, NY.

[81] Uy, M.A., Foo, M.D., \& Song, Z. (2013). Joint effects of prior start-up experience and coping strategies on entrepreneurs. Journal of Business Venturing, 28, 583-597.

[82] Van der Heijden, B. I. J. M., \& De Vos, A. (2015). Sustainable careers. In A. De Vos, \& B. I. J. M. Van der Heijden (Eds.) Handbook of research on sustainable careers (pp. 1-19). Cheltenham, UK: Edward Elgar Publishing.

[83] Williams, A. (2015, September 18). Move Over, Millennials, Here Comes Generation Z. New York Times.

[84] Zhao, H., Seibert, S. E., \& Lumpkin, G. T. (2010). The relationship of personality to entrepreneurial intentions and performance. Journal of Management, 36, 381-404.

[85] Addabbo, T., Rodríguez-Modroño, P., \& GálvezMuñoz, L. (2013). Gender and the Great Recession. IDEAS Working Paper Series from RePEc.

[86] Engemann, K., Wall, H. (2009). The Effects of Recessions Across Demographic Groups. Federal Reserve Bank of St. Louis Review, 92(1), 1-26.

[87] Verick, S. (2009). Who Is Hit Hardest during a Financial Crisis? IDEAS Working Paper Series, RePEc. [88] Deka, D. (2018). Are millennials moving to more urbanized and transit-oriented counties? Journal of Transport and Land Use, 11(1), 443-461. 